\title{
IN VITRO ANTIOXIDANT AND ANTICANCER ACTIVITY OF ULVA LACTUCA L.USING MOLT-3 CELL LINE
}

\section{CHIDAMBARARAJAN P*, KEERTHANA V, PRIYADHARSHINI K, SAKTHIVEL B}

\author{
Department of Biotechnology, Dr. N.G.P. Arts and Science College, Coimbatore, Tamil Nadu, India. Email: prchida@gmail.com
}

Received: 17 September 2018, Revised and Accepted: 18 March 2019

\section{ABSTRACT}

Objective: The aim of the present investigation was to determine the in vitro antioxidant and anticancer activity of the ethanol extract of Ulva lactuca L.

Methods: The present study was to investigate the antioxidant and anticancer activity of $U$. lactuca L. The extract of $U$. lactuca L. was extracted by ethanol and subject to analysis. An in vitro antioxidant activity of the ethanol extract of U. lactuca L. was performed by 1, 1-diphenyl-2-picrylhydrazyl free radical scavenging assay. Simultaneously anticancer activity was also performed using blood cancer (MOLT-3) cell line, and the species showed a strong selective cell proliferation inhibition of the cancer cell line.

Results: The scavenging activity was measured and determined to be $78.5 \%$. This might be due to high polyphenolic compounds and flavonoid contents of the extract, which showed maximum growth inhibition of $74.4 \%$.

Conclusion: Thus, the study concludes that the constituents of seaweeds can act as potent in treating various diseases and can be used as an alternative for therapeutic treatment.

Keywords: Seaweed, Ulva lactuca L., Ethanol extract, Antioxidant activity, Anticancer activity, MOLT-3 (human peripheral blood T lymphoblast and acute lymphoblastic leukemia).

(C) 2019 The Authors. Published by Innovare Academic Sciences Pvt Ltd. This is an open access article under the CC BY license (http://creativecommons. org/licenses/by/4. 0/) DOI: http://dx.doi.org/10.22159/ajpcr.2019.v12i5.29825

\section{INTRODUCTION}

Many marine organisms live in complex habitats exposed to extreme conditions and in adapting to new environmental surroundings. To survive under extreme conditions, these organisms also produce a wide variety of secondary (biologically active) metabolites which cannot be found in other organisms and seaweeds are valuable sources of macronutrients [1,2]. Ulva or sea lettuce species are some of the most abundant representatives, being ubiquitous in coastal benthic communities around the world. The ubiquitous genus Ulva has been included in relatively numerous physiological marine macroalgal studies [3]. Ulva lactuca is a widespread macroalgae occurring at all levels of the intertidal zone, in calm and protected harbors as deep as $10 \mathrm{~m}$ and northern climates. U. lactuca grows along rocky or sandy coasts of oceans and estuaries. In parts of Britain and Asia, seaweed is consumed by humans and livestock as it is considered valuable to human nutrition. The elemental analyses of seaweeds have been carried out in several countries by various techniques [4]. Researchers determined the chemical composition of Ulvaria oxsperma (Kützing Bliding), U. lactuca (Linnaeus), and Ulva fasciata (Delile). It is known that $U$. lactuca is evaluated for its nutritional value as food for ruminants, and goats [5].

The potential antioxidant compounds were identified as some pigments (fucoxanthin, astaxanthin, and carotenoid) (phenolic acid, flavonoid, and tannins). Seaweeds are noted that it contain not only labile antioxidants (i.e. ascorbate, glutathione) when it is fresh, but also has more stable molecules such as carotenoids, mycosporinelike amino acids and a variety of polyphenols (catechins and phlorotannins) [6,7]. The biochemical composition of marine seaweeds is generally known to be highly influenced by geographical location and local environmental condition [8]. Seaweed not only possesses nutrient potentials and but also have nutraceutical potentials such as antioxidant, antimutagenic, anticoagulant, anticancerous, and antibacterial activity [9]. Hence, seaweeds can be considered as promising plants forming one of the important marine living resources of high nutritional value. $20 \%$ of the Asian diet is comprised seaweeds that are relished not for their nutritional viewpoint but of unique and enchanting flavor. Seaweeds are getting importance in various fields ranging from food to medical [10]. The seaweed extract of U. lactuca L. can be used and recommended as an antifungal agent into prepare eco-friendly disinfectants [11].

The present investigation was to determine the in vitro antioxidant and anticancer activity of the ethanol extract of $U$. lactuca $\mathrm{L}$.

\section{MATERIALS AND METHODS}

Collection of seaweed

The seaweed U. lactuca L. (sea lettuce) was procured from the South coast areas, Rameswaram and Keelakarai, Latitude $9.280016 \mathrm{~N}^{\circ}$ and Longitude $79.129524 \mathrm{E}^{\circ}$ Tamil Nadu, India. The collected edible seaweed was identified and authenticated by Botanical Survey of India, Coimbatore, Tamil Nadu.

\section{Preparation of ethanolic extract}

The collected seaweed was washed thoroughly and shadow dried for 7 days [12]. The dried samples were grounded and powdered finely. $20 \mathrm{~g}$ of air-dried seaweed powder was added to $100 \mathrm{ml}$ of $70 \%$ ethanol and kept at $37^{\circ} \mathrm{C}$ for $6 \mathrm{~h}$ in an orbital shaker incubator. The final extract was obtained filtered by Whatman No.1 filter paper and concentrated to dry to yield crude extract residues. The final extract was diluted with solvents $(50 \mathrm{mg} / \mathrm{ml})$ and stored at $4 \mathrm{C}$ was used for further analysis. The percentage of yield was calculated using the formula:

$$
\text { Yield }(\%)=\left(\mathrm{W}_{1} \times 100\right) / \mathrm{W}_{2}
$$

Where $W_{1}$ was the weight of extract after evaporation and $W_{2}$ was the dry weight of the sample [13]. 
In vitro antioxidant activity

1,1-Diphenyl-2-picrylhydrazyl (DPPH) free radical scavenging activity

The DPPH scavenging activity was estimated according to the method described [14]. To the extracts (20-100 $\mu \mathrm{l}), 1 \mathrm{ml}$ of DPPH solution was added individually. The reaction mixture was incubated in the dark at for $30 \mathrm{~min}$ in room temperature. The absorbance was measured at $517 \mathrm{~nm}$ using UV spectrophotometer. L-Ascorbic acid was taken as a standard antioxidant. The percentage of DPPH free radical scavenging activity was calculated using the following equation:

$$
\text { Scavenging activity }(\%)=\frac{A_{\text {[sample] }}-A_{[\text {control] }}}{A_{[\text {controll] }}} \cdot 100
$$

\section{Anticancer activity}

\section{Cell culture}

The blood cancer (MOLT-3) cell line obtained from NCCS, Pune was maintained in humidified incubator at $37^{\circ} \mathrm{C}$ and in a $5 \% \mathrm{CO}_{2}$ atmosphere. RPMI-1640 contains $10 \%$ fetal bovine serum supplemented with antibiotics penicillin (100 units/ml) and Streptomycin (100 ug/ml).

\section{3-(4,5-Dimethylthiazol-2-yl)-2,5-diphenyltetrazolium bromide (MTT) assay}

An in vitro cytotoxicity study was performed using $U$. lactuca L. ethanol extract [15]. The culture medium from the MOLT-3 cells was replaced with fresh medium. The samples in triplicates were added on the cells. After incubation at $37 \pm 1^{\circ} \mathrm{C}$ for $18 \mathrm{~h}$, MTT $(\mathrm{mg} / \mathrm{ml})$ was added in all the wells and incubated for $4 \mathrm{~h}$. After incubation, dimethyl sulfoxide was added in the wells and read at $570 \mathrm{~nm}$ using photometer. Cytotoxicity and cell viability were calculated using the formula:

$$
\begin{gathered}
\text { Cytotoxicity }=\frac{\text { Control }- \text { Treated }}{\text { Control }}, 100 \\
\text { Cell viability }=\frac{\text { Treated }}{\text { Control }}, 100
\end{gathered}
$$

\section{RESULTS AND DISCUSSION}

\section{Extraction of seaweeds}

The dried and powdered seaweeds ( $20 \mathrm{~g}$ ) of U. lactuca L. were extracted with ethanol, which yielded a crude extract of $5 \mathrm{~g}$. The percentage of yield in U. lactuca L. was found to be $25 \%$.

\section{IN VITRO ANTIOXIDANT ACTIVITY}

\section{DPPH free radical scavenging assay}

Several studies have reported the free radical scavenging capacity of macroalgae. Seaweeds are low in fats, but they also contain vitamins and antioxidant molecules, such as phlorotannins, ascorbic acid, tocopherols, carotenoids, phospholipids, and chlorophyll related compounds [16]. Antioxidant activity of U. lactuca L. was evaluated using ethanol solvent. The marine seaweed sample was checked for its antioxidant activity by DPPH method; the ethanolic extract of the sample was checked in different concentrations from 20 to $100 \mu \mathrm{g}$. L-ascorbic acid was used as a standard antioxidant. Scavenging activity was observed during an increase in concentration of extract.

In the present study, $100 \mu \mathrm{g}$ of $U$. lactuca L. ethanol extract it shows the maximum antioxidant activity of $78.496 \%$ (Fig. 1). The higher activity in the ethanol extract of Ulva species may be due to their phenolic compounds within them. DPPH assay is one of the methods used for evaluating antioxidant activity [17]. The DPPH radical is a stable radical with a maximum absorbance at $517 \mathrm{~nm}$ due to the odd electron. The antioxidants can pair off this electron by hydrogen donation that causes a color change from purple to yellow, and the resulting decolorization is stoichiometric with respect to the number of electrons taken up [18].

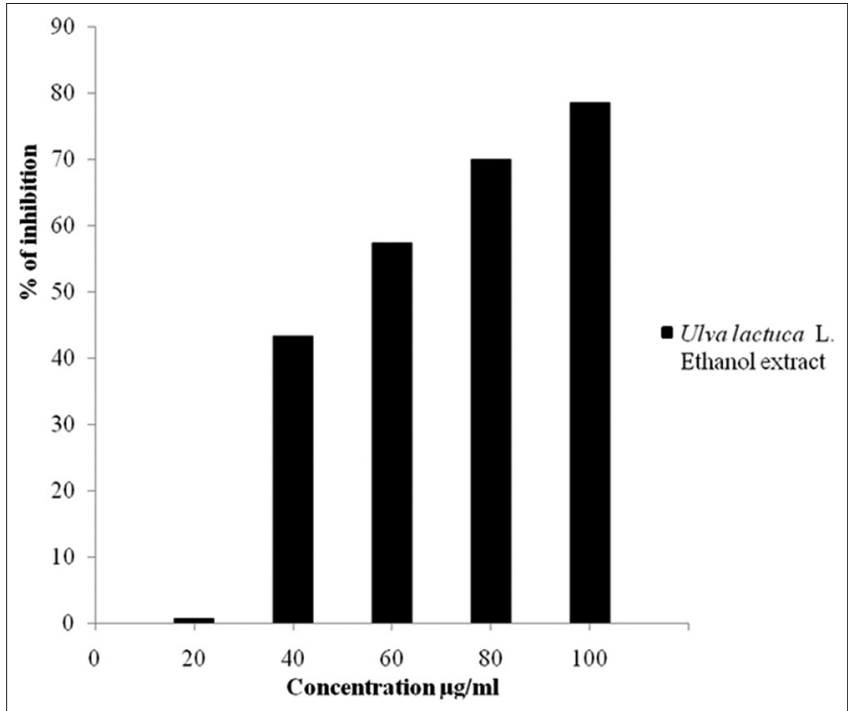

Fig. 1: 1,1-Diphenyl-2-picrylhydrazyl free radical scavenging activity of Ulva lactuca L. ethanol extract

The green and red algae do not contain a large amount of total phenolic content in comparison with brown algae, although higher values have been found in green algae when compared with red species. The results of the green algae Enteromorpha intestinalis with an $\mathrm{IC}_{50}$ value of 265.8 and $U$. lactuca with an $\mathrm{IC}_{50}$ value of 236.5 were higher than those for the red ones Palmaria palmata with an $\mathrm{IC}_{50}$ value of 76.9, Gracilaria vermiculophylla with an $\mathrm{IC}_{50}$ value of 95.2, Mastocarpus stellatus with an $\mathrm{IC}_{50}$ value of 102.5 , and Chondrus crispus with an $\mathrm{IC}_{50}$ value of 113.6. The extract from the green marine algae Caulerpa cupressoides contained higher content than the red marine algae Cordillacris crenulata, with the exception of extract from the green marine algae $U$. fasciata which was lower than that of the red marine algae A. multifida [19].

\section{Anticancer activity}

Blood cancer represents a large group of different malignancies. This group includes cancers of the bone marrow, blood, and lymphatic system, which includes lymph nodes, lymphatic vessels, tonsils, thymus, spleen, and digestive tract lymphoid tissue. Leukemia and myeloma, which start in the bone marrow, and lymphoma, which starts in the lymphatic system, are the most common types of blood cancer.

The abnormal cells in leukemia are usually found in the bone marrow and blood. The mechanism of leukemogenomic and autonomous proliferation of leukemia cells are still unknown. The mechanism and control of proliferation of leukemia cell lines with the characteristics of cells at different stages of leukemic development have been established.

In this investigation, the effect of $U$. lactuca $\mathrm{L}$. ethanol extract on MOLT-3 cell proliferation was studied. MOLT- 3 cells were exposed to different doses as shown in Table 1 and Fig. 2 of the seaweed extracts for $24 \mathrm{~h}$, and cell cytotoxicity and cell viability were checked by MTT assay. Cell viability was markedly decreased after treatment with different concentrations extract. The growth of cells was inhibited in a concentration and time-dependent manner.

The cytotoxicity and cell viability of MOLT-3 cell lines using green seaweed were investigated and the cytotoxic level of cells was performed by MTT assay. The tested algae extract $U$. lactuca $\mathrm{L}$. ethanol extract, showed a strong selective cell proliferation inhibition of the cancer cell line. This might be due to high polyphenols and flavonoids contents of the 100 $\mu \mathrm{g} / \mathrm{ml}$ extract, which showed maximum growth inhibition (74.4\%). The experimental observation in detected that cell death was a concentrationdependent process; hence, the number of non-viable cells increased with increasing concentration of algal extracts, the $U$. lactuca L. seaweed extracts showed significant cytotoxic activity. It is assumed that the presence 
Table 1: Cytotoxic activity of Ulva lactuca L. ethanol extract using MTT assay

\begin{tabular}{lllll}
\hline Description & Concentration $(\boldsymbol{\mu g})$ & Cytotoxicity $(\%)$ & Cell viability $(\%)$ & Cytotoxic reactivity \\
\hline Ulva lactuca $\mathrm{L}$. & 5 & 10.8 & 89.2 & Slight \\
& 25 & 39.5 & 60.5 & Mild \\
& 50 & 63.7 & 36.3 & Moderate \\
& 75 & 71.9 & 28.1 & Severe \\
\hline
\end{tabular}

MTT: 3-(4,5-Dimethylthiazol-2-yl)-2,5-diphenyltetrazolium bromide
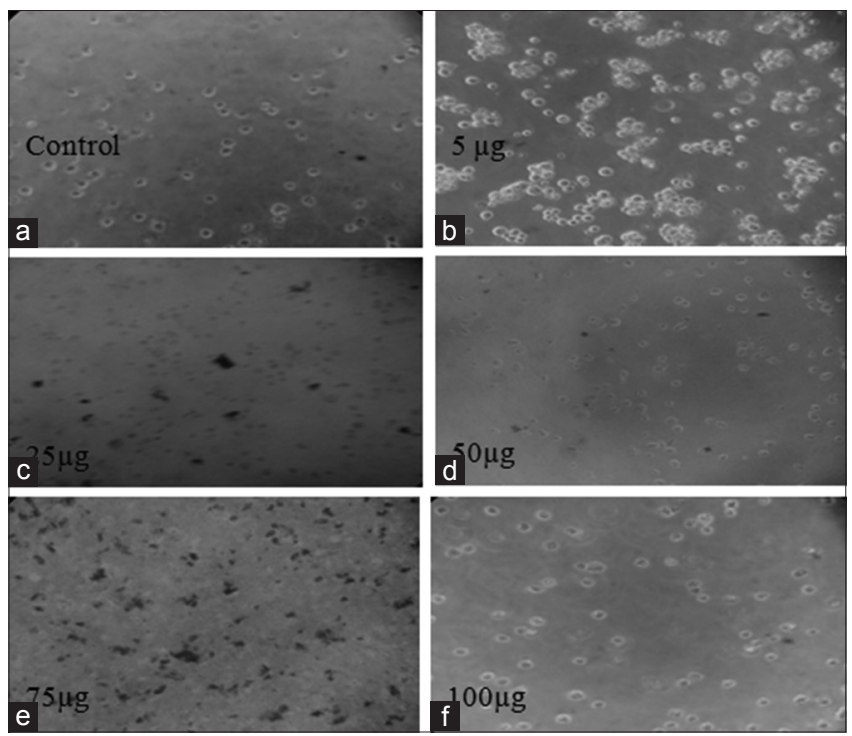

Fig. 2: (a-f) Cytotoxicity activity of Ulva lactuca L. ethanol extract on MOLT-3 cells

of polyphenolic compounds was the reason for observed free radical scavenging and anticancer activity. Mechanisms of antioxidant action can include suppression of reactive oxygen species (ROS) formation either by inhibition of enzymes or by chelating trace elements involved in the free radical generation, scavenging ROS, and upregulation or protection of antioxidant defenses [20]. The antioxidant activity of the methanolic extracts of Halophila ovalis and Halophila beccarii two seagrass species of Chilika lagoon was evaluated for DPPH and ABTS radical scavenging activities have strong antioxidant activity against ABTS and DPPH radicals. The seagrass species as a potential source of natural antioxidant for protection against several oxidative stress related diseases [21].

\section{CONCLUSION}

This study concludes that the ethanolic extract of $U$. lactuca L. seaweed possesses rich antioxidant property and may also contain polyphenolic compounds which may be responsible for the antioxidant property. The anticancer activity also shows that it has the capacity to kill the blood cancer cells in the human body. According to the results obtained from the study suggests that this seaweed can be the potential interest for food, development of novel drugs and functional foods, pharmaceutical and agricultural applications. Further research is needed to isolate and characterize the components responsible for their activities components and search for bioactive constituents with antimicrobial, antidiabetic and many other health-promoting activities.

The seaweed extracts Ulva lactuca L. showed slight to severe cytotoxic reactivity to MOLT- 3 cells after $24 \mathrm{~h}$ contact. Control gave none cytotoxic reactivity as expected.

\section{AUTHORS' CONTRIBUTIONS}

Keerthana V (VK) conceived the project. Chidambararajan P (PCR) supervised and guided the research work and preparation of the manuscript. Keerthana, Priyadharshini K (KP, and Sakthivel B (BS) collected and processed the samples and performed analysis, studied the scavenging activity, Performed and analyzed MTT assay. PCR and VK interpreted the data and prepared the manuscript. All authors read and approved the final manuscript.

\section{CONFLICTS OF INTEREST}

All authors report no conflicts of interest regarding this manuscript.

\section{REFERENCES}

1. Lordan S, Ross RP, Stanton C. Marine bioactives as functional food ingredients: Potential to reduce the incidence of chronic diseases. Mar Drugs 2011;9:1056-100.

2. Ortiz J, Romero N, Robert P, Araya J, Lopez Hernández J, Bozzo CE, et al. Dietary fiber, amino acid, fatty acid and tocopherol contents of the edible seaweeds Ulva lactuca and Durvillaea antarctica. Food Chemi 2006;99:98-104.

3. Beer S, Israel A. Photosynthesis of Ulva sp. III.02 effects, carboxylase activities, and the CO2 incorporation pattern. Plant Physiol 1986; 81:937-8.

4. Jung WK, Choi I, Oh S, Park SG, Seo SK, Lee SW, et al. Anti-asthmatic effect of marine red alga (Laurencia undulata) polyphenolic extracts in a murine model of asthma. Food Chem Toxicol 2009;47:293-7.

5. Villarreal-Gomez LJ, Irma EM, Graciela GR, Nahara ES. Antibacterial and anticancer activity of seaweeds and bacteria associated with their surface. Rev Biol Marina Oceanogr 2010;45:267-75.

6. Kakinuma M, Park CS, Amano H. Distribution of free L-cysteine and glutathione in seaweeds. Fish Sci 2009;67:194-6.

7. Yoshie Y, Wang W, Petilo D, Suzuki T. Distribution of catechins in Japanese seaweeds. Fish Sci 2000;66:998-1000.

8. Rohani-Ghadikolaei K, Abdulalian E, Ng WK. Evaluation of the proximate, fatty acid and mineral composition of representative green, brown and red seaweeds from the Persian Gulf of Iran as potential food and feed resources. J Food Sci Technol 2012;49:774-80.

9. Abirami RG, Kowsalya R. Nutrient and nutraceuticals potentials of seaweed biomass Ulva lactuca and Kappaphycus alvarezii. J Agric Sci Technol 2011;5:1939-250

10. Yu Qing T, Kaiser M, Ruqyia S, Muhammad FA. Ulva lactuca and its polysaccharides: Food and biomedical aspects. J Biol Agric Healthc 2016;6 Suppl 1:140-51.

11. Moorthi K, Kumar S. Antifungal activity of seaweed Ulva lactuca L. extracted cured protein against pathogenic fungi. Asian J Pharm Clin Res 2019;12 Suppl 3:393-6.

12. González del Val A, Platas G, Basilio A, Cabello A, Gorrochategui J, Suay I, et al. Screening of antimicrobial activities in red, green and brown macroalgae from Gran Canaria (Canary Islands, Spain). Int Microbiol 2001;4:35-40.

13. Yan X, Chuda Y, Suzuki M, Nagata T. Fucoxanthin as the major antioxidant in Hijikia fusiformis, a common edible seaweed. Biosci Biotechnol Biochem 1999;63:605-7.

14. Duan XJ, Zhang WW, Li XM, Wang BG. Evaluation of antioxidant property of extract and fractions obtained from a red alga, Polysiphonia urceolata. Food Chem 2006;95:37-43.

15. Monks A, Scudiero D, Skehan P, Shoemaker R, Paull K, Vistica D, et al. Feasibility of a high-flux anticancer drug screen using a diverse panel of cultured human tumor cell lines. J Natl Cancer Inst 1991;83:757-66.

16. Ogbiko C, Dabai MU, Amanabo M, Okoh EV, Bature BH. Antioxidant activity, total phenolic and flavonoid contents of the methanol whole plant extract of Elytraria marginata (Vahl). Afr J Biomed 2017;20:317-20

17. Ganesan P, Suresh Kumar K, Subba Rao PV. Comparative assessment of antioxidant activity in three edible species of green seaweed, 
Enteromorpha from Okha, Northwest coast of India. Innov Food Sci Emerg Technol 2011;12:73-8.

18. Sabeena Farvin KH, Jacobsen C. Phenolic compounds and antioxidant activities of selected species of seaweeds from Danish coast. Food Chem 2013;138:1670-81.

19. Ananthi S, Raghavendran HR, Sunil AG, Gayathri V, Ramakrishnan G, Vasanthi HR. In vitro antioxidant and in vivo anti-inflammatory potential of crude polysaccharide from Turbinaria ornata (Marine
Brown Alga). Food Chem Toxicol 2010;48:187-92.

20. Mishra A, Kumar S, Pandey AK. Scientific validation of the medicinal efficacy of Tinospora cordifolia. ScientificWorld Journal 2013;2013:292934.

21. Subrat KK, Suprava S, Basudeba K, Soumendra Kumar N, Pratap Chandra P. Antioxidant activity of Halophila ovalis and Halophila beccarii (Hydrocharitaceae): Two important seagras species of Chilika Lagoon, India. Asian J Pharm Clin Res 2019;12 Suppl 3:136-40. 